\title{
Effects of Monosodium Glutamate on the Liver of Male Adult Albino Rat and the Possible Protective Role of Vitamin C (Light and Electron Microscopic Study)
}

\author{
MOHAMED A. DOSUKY, M.D.*; DORREIA A. ZAGHLOL, M.D.**; SALWA M. OUIES, M.D.** and \\ HANAA A. ABDEL-NAEIM, M.Sc. $* * *$
}

The Departments of Anatomy \& Embryology, Faculty of Medicine, Al-Minia* \& Assiut** Universities and Human Anatomy \& Embryology, Faculty of Medicine, Sohag University***, Sohag, Egypt

\begin{abstract}
Background: Monosodium glutamate (MSG) is the sodium salt of glutamate. When MSG is added to foods, it provides a flavoring function similar to naturally occurring free glutamate. It is found in unlimited amounts in a wide variety of packaged foods such as processed meat, semi-preserved fish and food supplements. Vitamin $\mathrm{C}$ is a strong reducing agent and as an antioxidant. It is involved in prevention of the damaging effects of free radicals.
\end{abstract}

Aim of Work: The aim of this study was to study the potential protective effect of Vitamin C on liver damage caused by monosodium glutamate in adult male rats using light and Electron microscope.

Material and Methods: Sixty adult albino rats were used. The animals were equally divided into three groups each of them consists of 20 rats: Group I: "Control" were given saline daily by oral route "for one month. Group II: Were given monosodium glutamate ( $4 \mathrm{gm} / \mathrm{kg}$ of body weight/day, dissolved in saline orally) for one month. Group III: Were given vitamin $\mathrm{C}(500 \mathrm{mg} / \mathrm{kg}$ of body weight of /day, orally) then after 2 hours were given monosodium glutamate (4gm/ $\mathrm{kg}$ of body weight/ day, dissolved in saline orally) for one month. At the end of the experiment, the rats were anaesthetized by ether then perfused with saline then with the appropriate fixator (Formalin $10 \%)$. The abdomen was opened and the liver of the control and treated animals was extracted, cut, and processed for light and transmission electron microscopic studies.

Results: MSG caused distortion of the arrangement of liver cords around the central veins. There was vacuolation of hepatocytes of the liver at light and electron microscopic examination and morphmetric studies. Administration of Vitamin $C$ could attenuate these changes.

Conclusion: MSG caused degenerative changes in the liver. Addition of vitamin $\mathrm{C}$ decreased those toxic effects of MSG.

Key Words: Liver - Monosodium glutamate - Vitamin C.

Correspondence to: Dr. Mohamed A. Dosuky,

The Departments of Anatomy \& Embryology,

Faculty of Medicine, Al-Minia University

\section{Introduction}

MONOSODIUM glutamate (MSG) is commonly consumed as a flavor enhancer or food additive $[1,2]$. MSG is the sodium salt of the non-essential amino acid-glutamic acid [3]. MSG contains $78 \%$ of glutamic acid, $22 \%$ of sodium and water [4]. It is known to have some adverse effects in humans and experimental animals. It is metabolized in liver and eliminated through the kidney [5]. Glutamic acid is transformed into alanine in intestinal mucosa and lactate in liver [6]. Chronic administration of MSG $>$ _ $(4 \mathrm{mg} / \mathrm{k})$ induced oxidative stress in experimental animals.MSG causes retinal degeneration, endocrine disorder, addiction, stroke, epilepsy, brain trauma, neuropathic pain, schizophrenia, anxiety, depression, Parkinson's disease, Alzheimer's disease, Huntington's disease, and amyotrophic lateral sclerosis $[\mathbf{7 , 8 ]}$. Subsequently it was documented that MSG produces oxygen derived free radicals [9]. It is reported that MSG (2mg/gm of b.w) causes changes in the liver parenchyma of mice around central vein, dilated sinusoids, inflammatory cells and nuclei were pyknotic [6]

Vitamin C (L-ascorbic acid) is an essential nutrient for humans and certain other animal species. In living organisms, L-ascorbic acid acts as an antioxidant by protecting the body against oxidative stress. It is a powerful reducing agent capable of rapidly scavenging a number of reactive oxygen species (ROS). Ascorbic acid is a wellknown for its antioxidant activity, acting as a reducing agent to reverse oxidation. When there are more free radicals (reactive oxygen species "ROS") in the human body than antioxidants, the condition is called oxidative stress. It prevents 
oxidative damage to the important biological macromolecules, such as DNA, proteins and lipids. Some investigators reported that antioxidants inhibited chemical carcinogenesis hen the antioxidants are administered either prior or with carcinogen [10].

Ascorbic acid (vitamin C) has protective role against acute ultraviolet B-rays (Sunburn cell formation), organophosphorous pesticides and could reduce aflatoxin induced liver cancer [11] Moreover vitamin $\mathrm{C}$ abolishes chromosome damage resulted from the effect of toxic substances and help to protect the body against pollutants.Vitamin $\mathrm{C}$ is a biological reducing agent, it prevents the degenerative diseases such as cataracts, certain cancer and cardiovascular disease [12].

\section{Aim of the work:}

The aim of this work was to study the potential protective effect of Vitamin $\mathrm{C}$ on liver damage caused by MSG in adult male rats by histological and ultrastrucural study.

\section{Patients and Methods}

The research was done in 2016. A total number of sixty adult male albino rats (average weight $180-200 \mathrm{gm}$.) were brought from the animal house of Sohag Faculty of Science. They were reared under the standard conditions of feeding, lightdark ratio and temperature.

\section{Animal Used:}

- Group (I) [Control Group]:Were given $1 \mathrm{ml}$ of saline daily by oral route for one month.

- Group (II) [Monosodium glutamate Treated Group]: Were given monosodium glutamate $(4 \mathrm{gm} / \mathrm{kg}$ of body weight/day, dissolved in saline orally) for one month [13].

- Group (III) [Vitamin C-Monosodium glutamate Treated Group]: Were given vitamin C (500mg/ $\mathrm{kg}$ of body weight of day, orally) [14] then after 2 hours given monosodium glutamate $(4 \mathrm{gm} / \mathrm{kg}$ of body weight/day [13], dissolved in saline orally) for one month.

Monosodium glutamate was obtained from Morgan Company for Chemical Industry (Tenth of Ramadan City, Egypt). Vitamin C (L-ascorbic acid) was obtained from Egyptian pharmaceutical industries company. MSG was in the form of powder. Vitamin $\mathrm{C}$ was in the form of powder, dissolved in saline and each rat was given $1.5 \mathrm{~cm}$ MSG and $0.5 \mathrm{~cm}$ vitamin $\mathrm{C}$ orally via syringe (gastric tube).
At the end of the experiment, the rats were anaesthetized by ether then perfused with saline then with the appropriate fixator (Formalin 10\%). The abdomens were opened and the liver of the control and treated animals was extracted, cut, and processed for light and transmission electron microscopic studies.

For light microscopic study: The specimens were fixed in $10 \%$ neutral buffered formalin and processed for light microscopic study to get paraffin sections of 6 mickness. Sections were stained with Haematoxylin and Eosin (H\&E), Masson's Trichrome stain and periodic Acid-Schiff (PAS).

For transmission electron microscopic study (TEM): Specimens were cut in small pieces and fixed in $2.5 \%$ glutaraldehyde for 24 hours. Then specimens were washed by sodium cocodylate buffer solution, postfixed in $1 \%$ osmium tetraoxide in sodium cacodylate buffer for two hours, then washed and dehydrated in ascending grades of alcohol, ehanol 30\%, 50\%, 70\%, 95\%. The specimens were embedded in Mollenhauer's EponAraldite formulation and the tissue blocks were polymerized in an oven. Blocks were trimmed with a razor blade and cutting was done by a glass knife in KLB ultramicrotome. Semithin sections were stained with Toluidine blue. Ultrastructural sections were mounted on copper grids, stained with Uranyl acetate and Lead citrate and ultrathin sections were examined by transmission electron microscope (Jeol-1010) in Assiut University.

\section{Morphometric and statistical analysis:}

Estimation of the mean diameters of the hepatocytes and central veins (maximum diameter) in each lobule (at magnification 400) was done in each group. Measurements were performed in Haematoxylin and Eosin (H\&E) sections, 2-3 sections per animal. In each section five measurements were obtained from five randomly chosen fields using image analysis system (digimizer version 3.7.2005-2010) med-calc software in the Anatomy Department at Sohag University.

\section{Statistical analysis:}

Statistical analysis of measurements of mean diameters of the hepatocytes and central veins were done using SPSS soft ware version 16.Variables were represented by mean \pm SD (mean \pm standard deviation of mean). One way ANOVA was used to compare the means of these variables between different groups. Finally the significance was considered according to the level of significance $p$ value as follows: 
$\bullet p>0.05$ non significant.

- $p \leq 0.05$ significant*.

- $p \leq 0.01$ highly significant**.

- $p \leq 0.001(* * *) \rightarrow$ Very high significant difference.

\section{Results}

Group I (Control group):

Histological study:

Light microscope:

$H x \& E \&$ Toludine blue: In the control liver; the normal architecture of the hepatic tissue was clear. The hepatic lobule consisted of the central vein in the center of the lobule and cords of hepatocytes radiating from the center towards the periphery (Figs. 1,2,3).

The hepatocytes appeared polyhedral in shape with centrally located rounded vesicular nuclei. Some hepatocytes were binucleated. The cytoplasm of hepatocytes appeared acidophilic with basophilic granules. Blood sinusoids were observed inbetween hepatocytes and were lined by flat endothelial cells. In the periphery of the lobules, there are portal areas (triad) which contains small areas of connective tissue enclosing bile ducts, branch of hepatic artery and a branch of portal vein (Figs. $3,4)$.

Masson's Trichrome: Masson's Trichrome stained sections showed the minimal distribution of collagen fibers around the central vein and portal tracts. Minimal collagen fibers were also identified between cords of hepatocytes (Fig. 5).

P.A.S stained liver sections, the cytoplasm of hepatocytes in the control rats gave a highly positive reaction that appeared as pink mucopolysaccharide granules of different sizes (Fig. 6).

\section{Ultra structurally:}

The hepatocyte appeared with large rounded nucleus with prominent nucleolus. The cytoplasm was crowded with mitochondria and rough endoplasmic reticulum (RER) (Fig. 7). Small oval shape Kupffer cell with euchromatic kidney shaped nucleus also was noticed (Fig. 8).

\section{MSG treated group (Group II):}

\section{By Hx\&E\& Toludine blue:}

The liver architecture was somewhat distorted; around the central veins with diffuse areas of faintly stained hepatocytes (Fig. 9). The central vein and the blood sinusoids were markedly dilated. Lym- phocytic infiltration appeared. Congestion was observed at the central veins and portal tracts (Figs. $9,10)$.

Congested blood sinusoids were noticed between the vacuolated hepatocytes, inflammatory cellular infiltration was also appeared around portal tract and sinusoids. Some hepatocytes had deeply stained nuclei. Other hepatocytes appeared with vacuolation of their cytoplasm. There were abundant small fragmented pycnotic nuclei around the central vein (Figs. 11,12,13). Enlarged detached Kupfer cells were also noticed (Fig. 12).

\section{Masson's trichrome:}

Dense Strands of collagen fibers were seen radiating from the central veins and extending between hepatocytes and around blood vessels and the bile duct in the portal area (Fig. 14).

P.A.S stained sections: showed mosaic arrangement and heterogenic distribution of P.A.S.-positive reaction. In that respect, some of them showed a moderate P.A.S. reaction, whereas others showed minimal reaction in the hepatocyte cytoplasm (Fig. $15)$.

\section{Ultrastructrally:}

Hepatocytes were markedly affected. The hepatocyte was severly shrunken. The nucleus had clumping heterochromatin with abnormal nuclear envelope. The cytoplasm was rarified. The hepatocytes showed vacuolated cytoplasm, swollen mitochondria and vesiculated rough endoplasmic reticulum. The nuclear membrane was corrugated, endothelial cell (Fig. 16). Irregular border Kupffer cell with destructed cytoplasm (Fig. 17).

Group III (Rats that received vitamin $\mathrm{C}+$ monosodium glutamate):

Light microscope:

$H x \& E \&$ Toluidine blue: The livers of the rats in group III showed some improvement when compared with those in group II. Rats liver sections showed restoration of the liver architecture (Fig. 18).

The hepatocytes were arranged as regularly radiating cords around the central veins. Normal hepatocytes could be seen while other hepatocytes showed minimal vacuolation. Hepatocytes restored their size. Blood sinusoids in the vicinity of the central veins were apparently normal, while others were dilated and congested (Figs. 19,20,21). Kupfer cells restored their size (Fig. 21). 


\section{Masson's trichrome stain:}

Liver sections showed that the collagen fibers between the cords of hepatocytes were almost as in the control groups with minimal deposition around the central vein and portal tract (Fig. 22).

\section{P.A.S. stain:}

Sections stained by P.A.S. stain demonstrated moderately positive P.A.S. reaction in hepatocyte cytoplasm, others with somewhat decrease glycogen contents (Fig. 23).

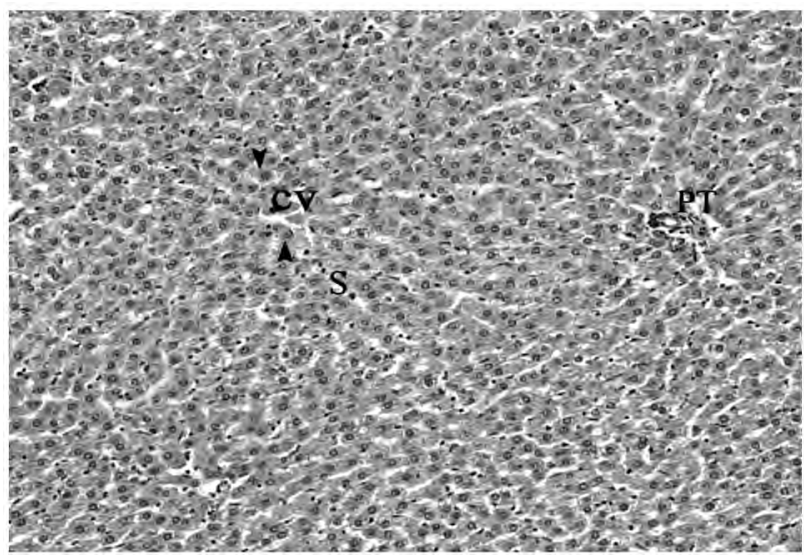

Fig. (1): A photomicrograph of a section of liver of a control rat showing central vein (C.V) with cords of hepatocytes (arrow heads) radiating from it, separated by blood sinusoids (S); Note: Portal tract (PT). (H\&E. X200).

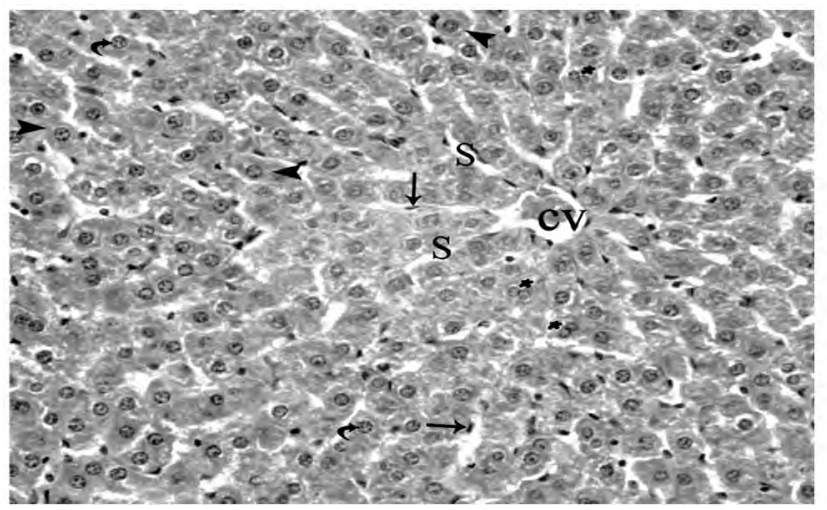

Fig. (3): A photomicrograph of a section of liver of a control rat (group I) showing; central vein (C.V) with cords of hepatocytes (arrow head) radiating from it. Hepatocytes with vesicular nuclei (curved arrows) and separated by blood sinusoids (S) lined with kupfer cells (thin arrow). (H\&E. X400).

\section{Ultrastructurally:}

Rats treated with Vitamin C with Monosodium glutamate showed an improvement in the ultrastructural changes in the form of diminution of cytoplasmic dissolution and a well-defined large nucleolus and nuclear envelope. There were normalshaped rough endoplasmic reticulum. The mitochondria were still dilated, Normal shape endothelial cell was noticed (Fig. 24). Well defined border Kupffer cell with kidney shaped nucleus also noticed (Fig. 25).

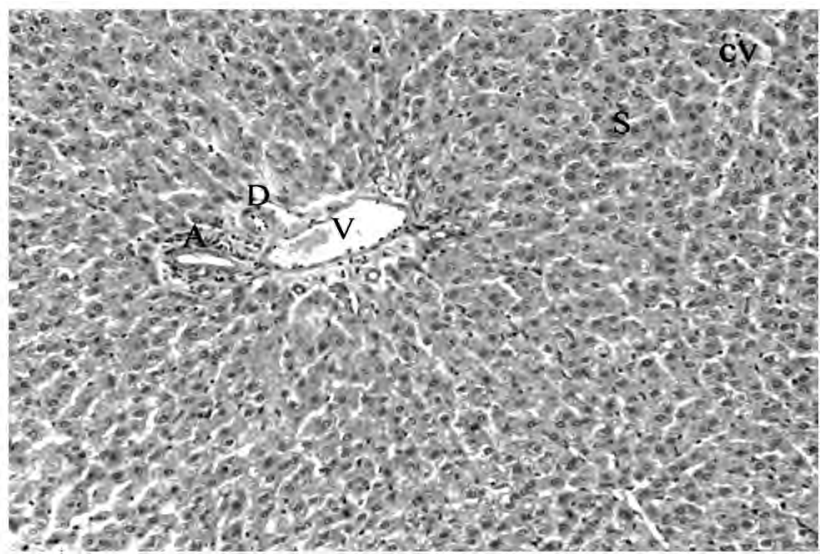

Fig. (2): A photomicrograph of a section of liver of a control rat showing central vein (C.V) with cords of hepatocytes (arrow heads) radiating from it, separated by blood sinusoids (S), Portal tract (hepatic artery (A), vein (V) and bile duct (D). (H\&E. X200)

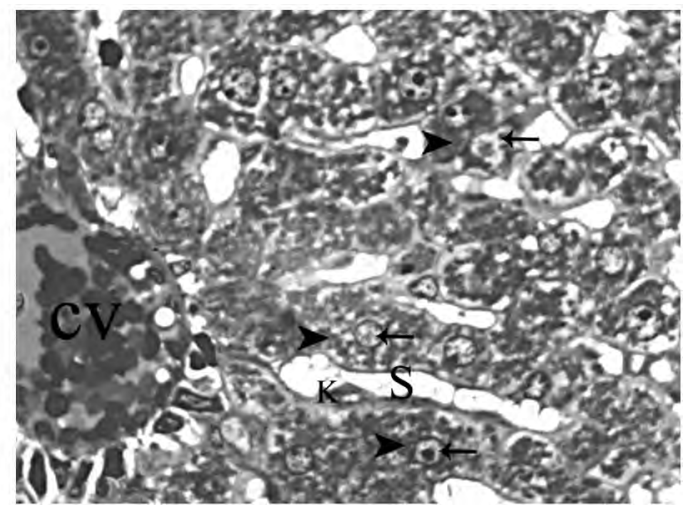

Fig. (4): A photomicrograph of semithin section in liver of a control rat (group I) showing; the central vein (C.V) with cords of hepatocytes radiating from it, basophilic granules (arrow head), vesicular nucleus (arrow), blood sinusoids (S) seen between the hepatocytes. Note kupfer cell (K). (Toluidine blue X1000). 


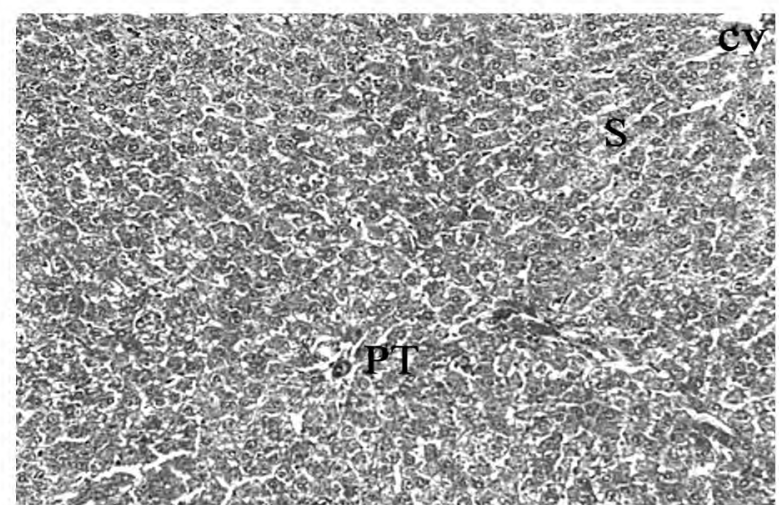

Fig. (5): A photomicrograph of a liver section of a control rat (group I) showing minimal stromal collagen fibers (green colored) around central vein $(\mathrm{CV})$ and portal tract (PT); Note: Sinusoid (S). Masson's trichrome (X200).

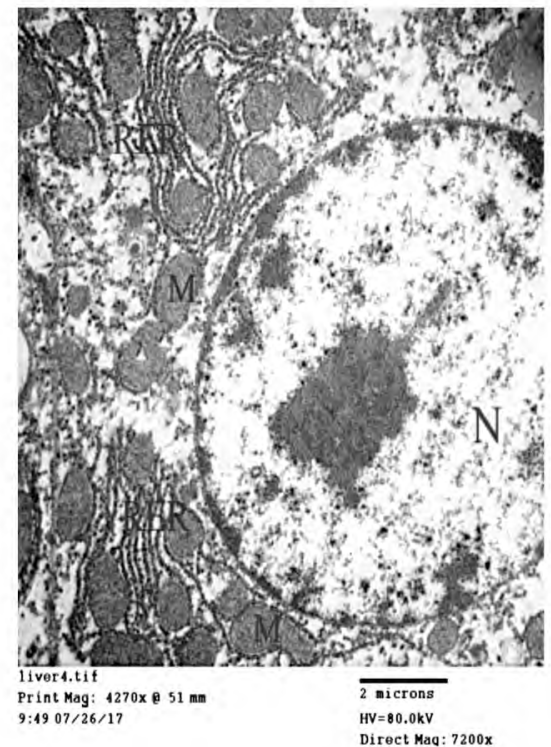

Fig. (7): An electron micrograph of a hepatocyte in liver of (group I) showing; a large rounded centrally located nucleus $(\mathrm{N})$ with prominent nucleolus, large number of mitochondria (M) and large numbers of rough endoplasmic reticulum (RER). (X 7200)

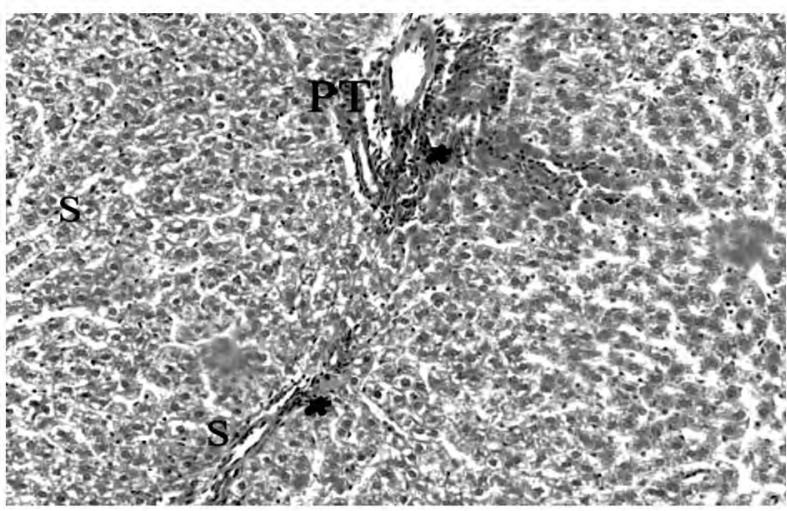

Fig. (9): A photomicrograph of a section of liver of MSG treated rat (group II) inflammatory cells (Asterisks) around portal tract (PT) and around sinusoids. (H\&E. X200).

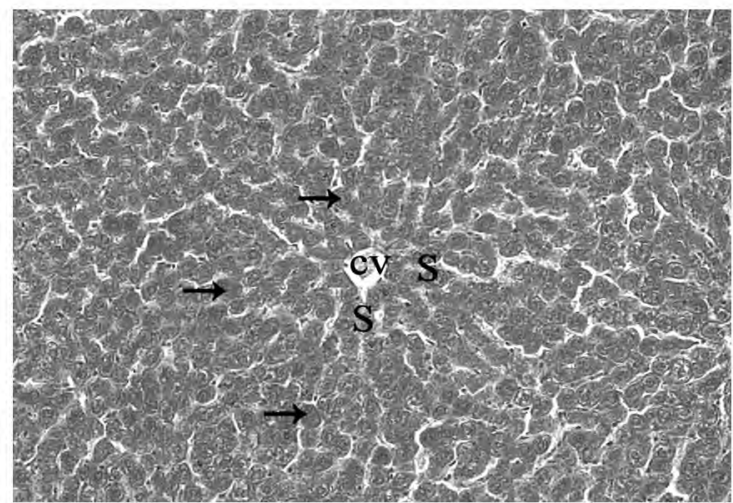

Fig. (6): A photomicrograph of a liver section of a control rat (group I) showing positive diffuse P.A.S. reaction uniformly distributed in the hepatocyte cytoplasm (arrows).P.A.S. (X200).

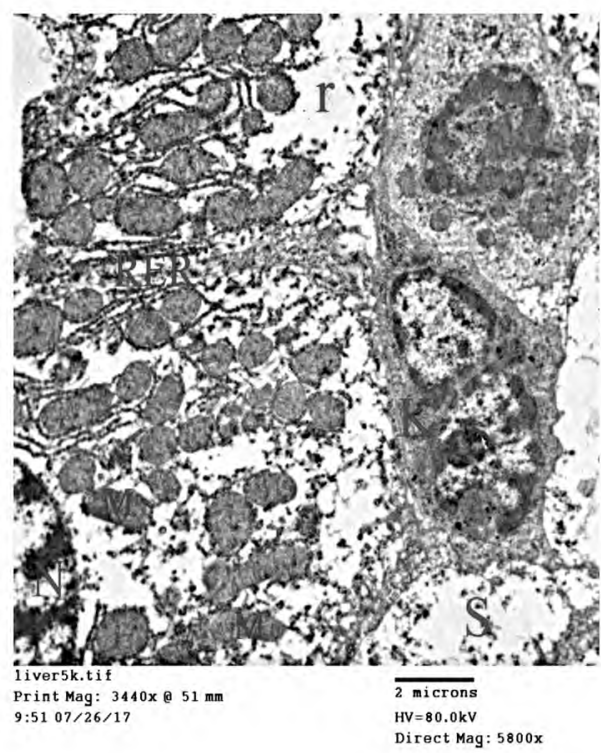

Fig. (8): Transmission electron photomicrograph from liver of a contro rat (group I) showing hepatocytes showing rounded nucleus $(\mathrm{N})$, mitochondria (M) small oval shape Kupffer cell (K) which has euchromatic kidney shaped nucleus, rarified cytoplasm (r) and sinusoid (S). (x 5800).

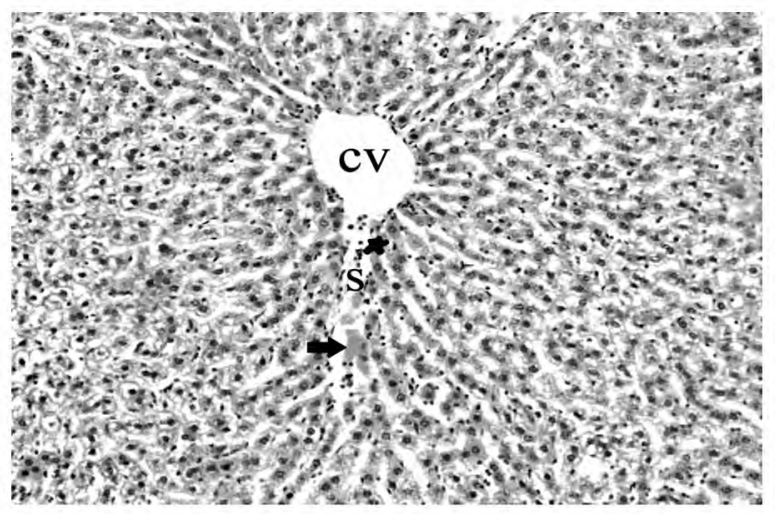

Fig. (10): A photomicrograph of a section of liver of MSG treated rat (group II) distortion of the arrangement of liver cords around the central veins (C.V), dilated blood sinusoids (S), inflammatory cells (Asterisks) around central vein and sinusoid, haemorrhage (thick arrow) in sinusoid. (H\&E. $\mathrm{X} 200$ ). 


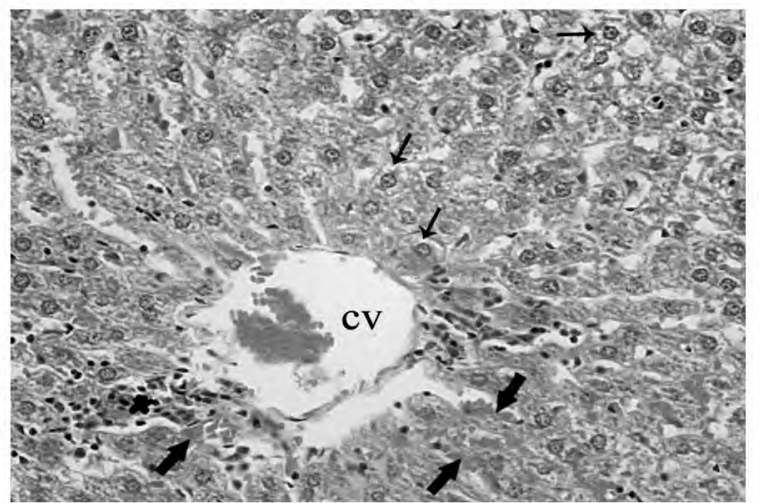

Fig. (11): A photomicrograph of a liver section of MSG treated rat (group II) showing distortion of arrangement of liver cords around the dilated and congested central vein $(\mathrm{CV})$. The majority of hepatocytes are vacuolated (thin arrows). Only few hepatocytes appear normal, congestion of blood sinusoids and haemorrhage between hepatocytes (thick arrows), inflammatory cells between hepatocytes (astrisk). (H\&E $\mathrm{X} 400)$.

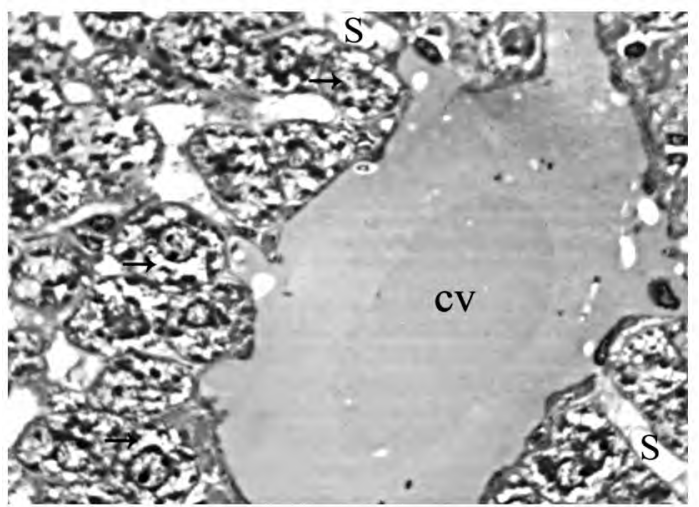

Fig. (13): A photomicrograph of semithin section in liver of MSG treated rat (group II) showing; marked congested central vein (C.V), shrinkage and degeneration of hepatocytes with vacuolated cytoplasm (arrows); Note: dilated sinusoids (S). (Toluidine blue X1000).

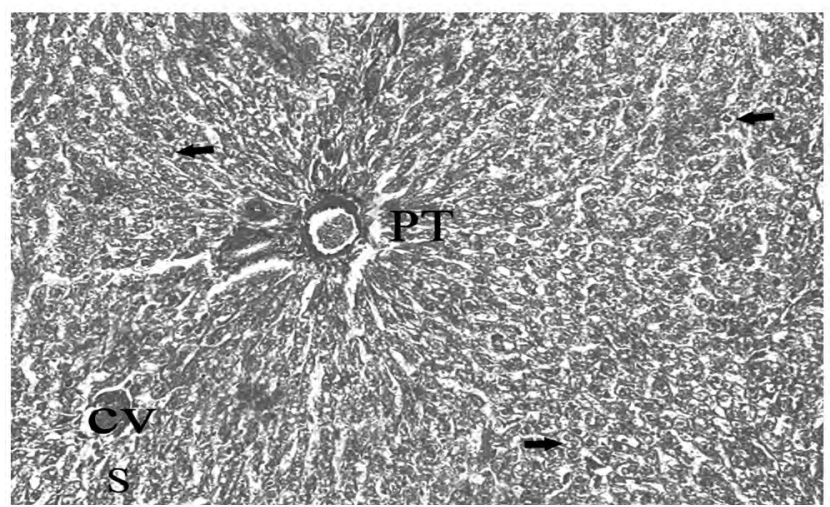

Fig. (15): A photomicrograph of a liver section of MSG treated rat (group II) showing mosaic appearance of hepatocytes, areas of marked decrease in glycogen content of cells (thick arrows) and others with moderate glycogen content (thin arrows).Note the central vein (CV), sinusoid (S) and portal tract (PT). P.A.S. (X200)

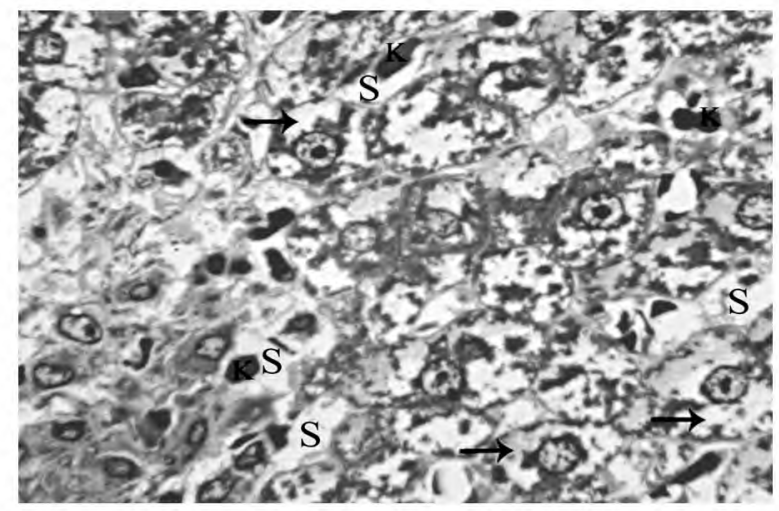

Fig. (12): A photomicrograph of semithin section in liver of MSG treated rat (group II) showing; abnormal clumping of the basophilic cytoplasmic granules; minimal basophilic granules (arrows), dilatation in blood sinusoids (S) and large kupfer cells (K). (Toluidine blue X1000).

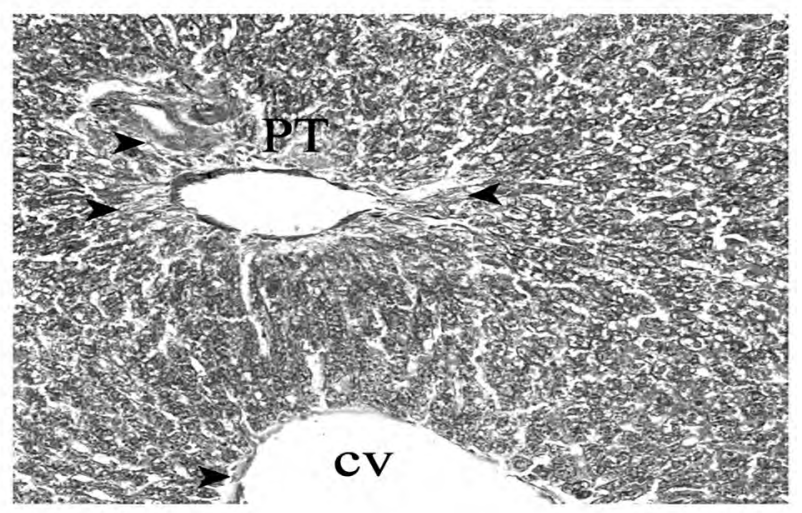

Fig. (14): A photomicrograph of a liver section of MSG treated rat (group II) showing dense green collagen fibers (Arrow heads) around the central vein (CV) and around portal tract (PT). Masson's trichrome (X200).

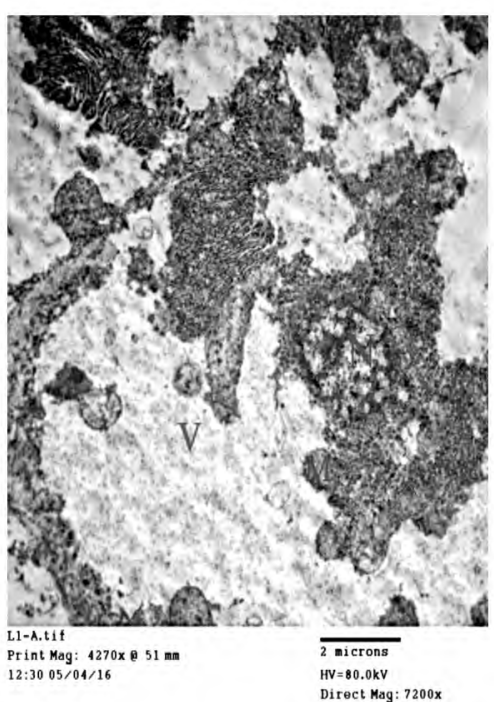

Fig. (16): Transmission electron micrograph of hepatocytes of MSG treated rat (group II); showing degenerated nucleus $(\mathrm{N})$, vacuolated cytoplasm $(\mathrm{V})$, shrunken mitochondria $(\mathrm{M})$ with depletion in number and vesiculated rough endoplasmic reticulum (RER). (x7200). 


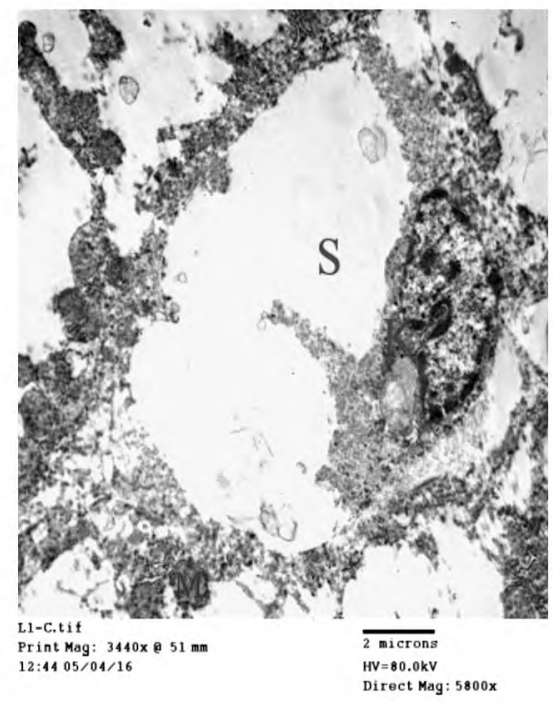

Fig. (17): Transmission electron micrograph of hepatocytes of hepatocytes of MSG treated rat (group II) showing irregular border Kupfer cell (K) and sinusoid (S). (x 5800).

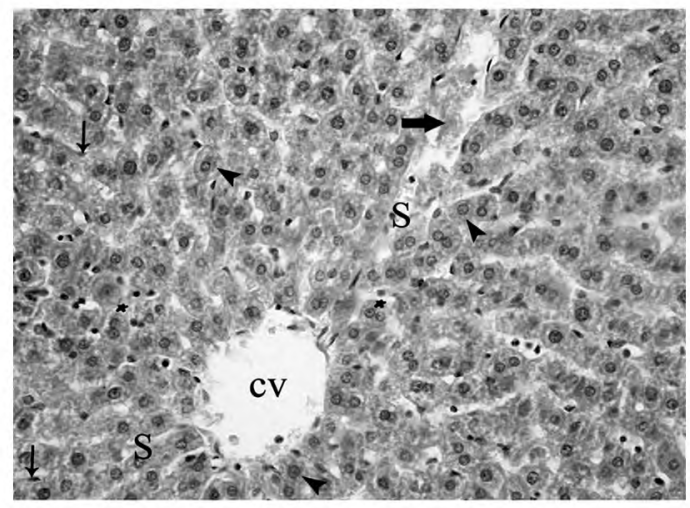

Fig. (19): A photomicrograph of a liver section of Vit $C$ treated rat (group III), showing a central vein (CV) surrounded by normal hepatocytes (arrow head), congested dilated sinusoid (thick arrow); Note the sinusoids (S) and kupffer cells (thin arrows). H\&E (X400)

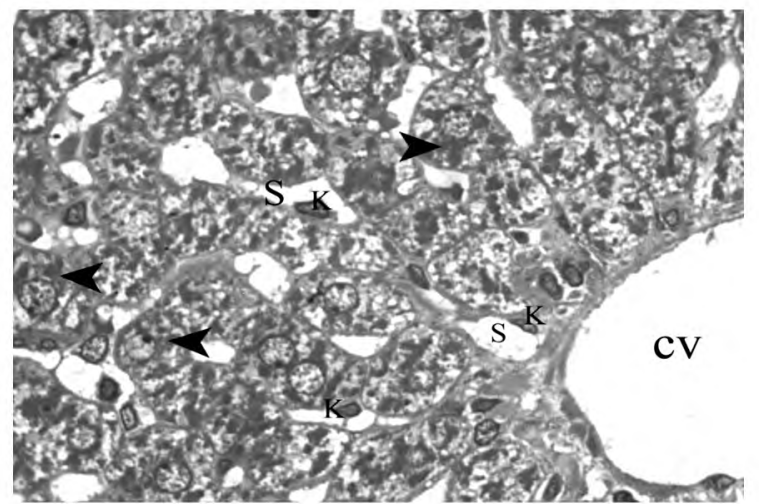

Fig. (21): A photomicrograph of semithin section in liver of Vit C treated rat (group III) showing; hepatocytes restored their size and basophilic bodies (arrow heads), hepatocytes separated by sinusoids (S); Kupfer cells (K) restored their size, Note the central vein (C.V). (Toluidine blue X1000).

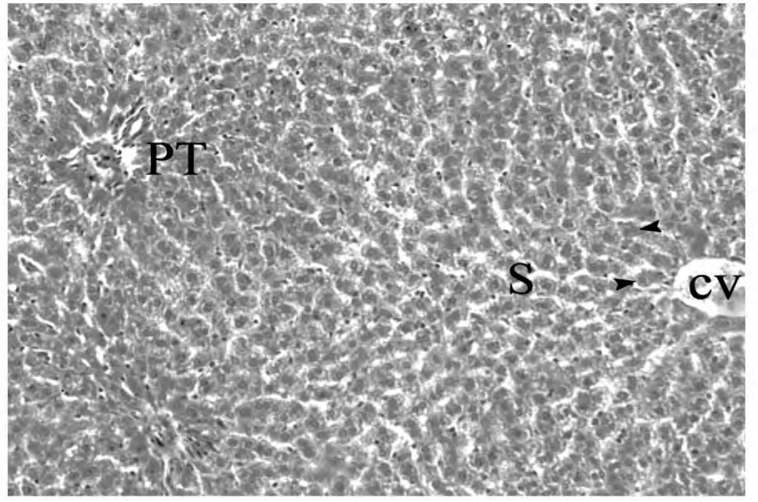

Fig. (18): A photomicrograph of of a liver section of Vit $\mathrm{C}$ treated rat (group III), showing a central vein (CV) surrounded by normal hepatocytes, sinusoid (S), hepatocytes (arrow head) and portal tract (PT). H\&E (X200)

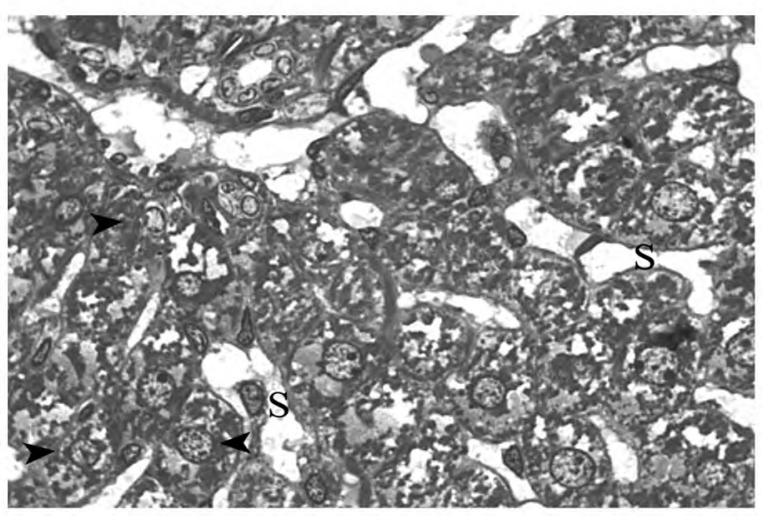

Fig. (20): A photomicrograph of semithin section in liver of Vit C treated rat (group III) showing; hepatocytes restored their sizes and basophilic bodies (arrow heads), hepatocytes separated by sinusoids (S). (Toluidine blue X1000)

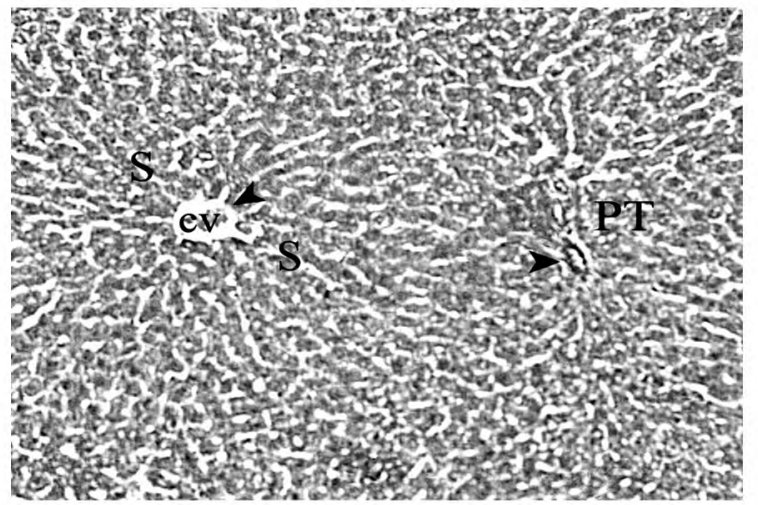

Fig. (22): A photomicrograph of a liver section of Vit $C$ treated rat (group III) showing the minimal amount of connective tissue (head arrows) surrounding the central vein $(\mathrm{CV})$ and portal tract (PT). Masson's Trichrome (X200). 


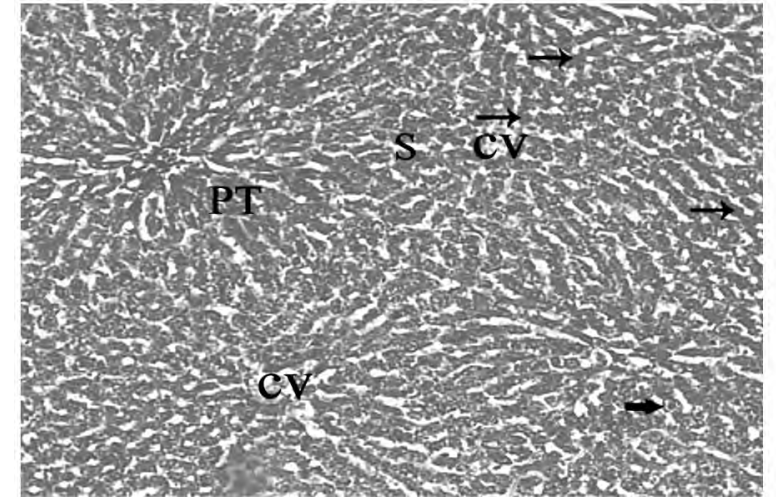

Fig. (23): A photomicrograph of a liver section of Vit C treated rat (group III) showing moderate positive P.A.S. reaction (thin arrows) in the cytoplasm of hepatocytes in the form of granules. Glycogen content somewhat decreased in the cells (thick arrows), central vein (CV) and sinusoid (S) restored their normal size. P.A.S. (X200).

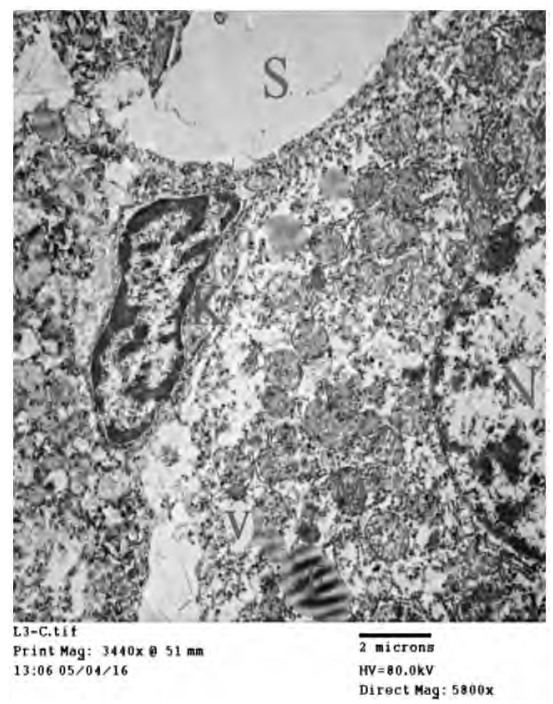

Fig. (25): Transmission electron Micrograph of Vit C treated rat (group III) showing hepatocytes with large rounded euchromatic nucleus $(\mathrm{N})$ and, kupffer cell $(\mathrm{K})$ with kidney shaped nucleus, Note the sinusoid (S) and dilated mitochondria (M). (x 5800).

\section{Morphometric study:}

- Diameter of hepatocytes: (Table 1, Diagram 1)

Mean hepatocyte diameter in group II (117.9419 pixels) showed a significant change $(p=0.000)$ when compared with group I (140.9587) and group III (133.7265 pixels).

There was a non significant change $(p=0.059)$ between group I \& group III.

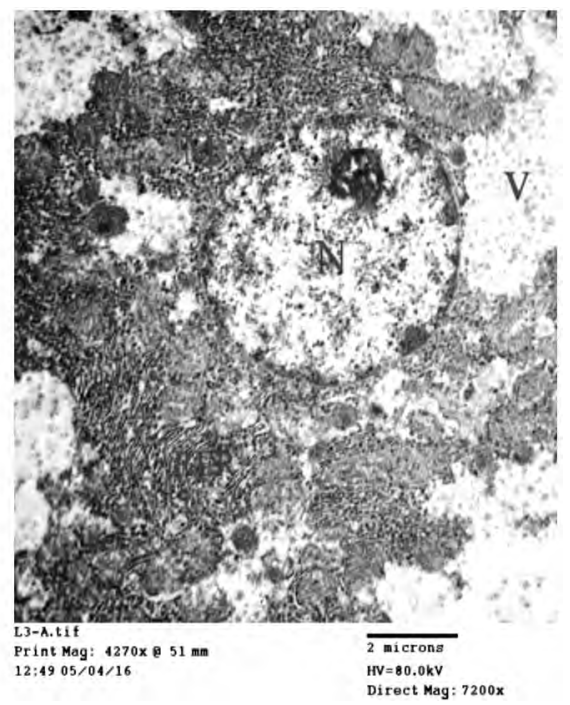

Fig. (24): Transmission electron micrograph of hepatocytes of Vit C treated rat (group III) showing large rounded euchromatic nucleus $(\mathrm{N})$. Dilated mitochondria $(\mathrm{M})$; Note the rough endoplasmic reticulum (RER). (x 7200)

- Diameter of central vein: (Table 1, Diagram 1)

Mean central vein diameter in group II ( 944.8613 pixels) showed a significant change $(p=$ $0.001)$ when compared with group I (434.6657) and group III (536.9453 pixels).

There was a non significant change $(p=0.139)$ between group I \& group III.

- The mean diameter (in pixels) of hepatocytes; $p \leq 0.001 \rightarrow$ high significant.

- The mean diameter (in pixels) of central veins; $p \leq 0.001 \rightarrow$ high significant difference.
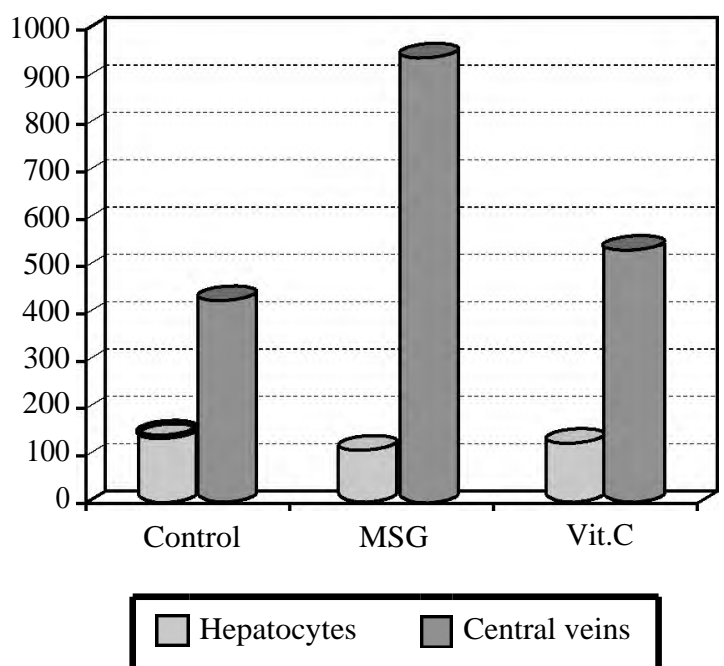

Diagram (1): The mean diameter (in pixels) of hepatocytes and central veins. 
Table (1): The mean diameter (in pixels) of hepatocytes and central veins.

\begin{tabular}{lccccccc}
\hline Parameters & GI & GII & GIII & $p_{1}$-value & $p_{2}$-value & $p_{3}$-value & $p$-value \\
\hline Diameter of hepatocytes (Pixels) & 140.9587 & 117.9419 & 133.7265 & 0.000 & 0.059 & 0.001 & 0.000 \\
Diameter of central veins (Pixels) & 434.6657 & 944.8613 & 536.9453 & 0.002 & 0.139 & 0.012 & 0.001 \\
\hline$p 1=$ Comparison between group I \& group II & \multicolumn{5}{c}{$p 2=$ Comparison between group I \& group III. } \\
$p 3=$ Comparison between group II \& group III. & & \multicolumn{5}{c}{}
\end{tabular}

\section{Discussion}

MSG flavor is gained immense popularity worldwide and has been used widely in restaurants, packaged food industries and household kitchens. Modern commercial MSG is produced by fermentation of starch, sugar, beet, sugarcane or molasses [15].

Although MSG was reported to have toxic effects in different organs of the animals and human, it remains one of the most studied materials in the world food supply [16]

Although the Food and Drug Administration (FDA) has classified MSG as a food ingredient that's "generally recognized as safe", the use of MSG remains controversial. For this reason, when MSG is added to food, the FDA requires that it be listed on the label [17].

Liver and tissues metabolize glutamate by oxidative deamination (or transamination to oxaloacetic or pyruvic acid via alpha-ketoglutarate to succinate [18]

The results of light microscope of Group (II) (Group treated with MSG) were confirmed by other studies that attributed the observed degenerative changes to the cytotoxic effect of MSG on the liver, thereby affecting the normal detoxification process and other functions of the liver $[19,20]$ It was also reported that MSG administration had led to an increase in the enzyme activity (ALT and AST) indicating hepatocellular injury and possibly liver cirrhosis [21,22].

A study noted that the vacuolation of hepatocytes were more pronounced around the central vein in the mice injected by MSG for 75 days [23]

The vacuolation of hepatocytes as ballooning degeneration and interpreted it as a kind of cellular defensive mechanism against injurious substances [24].

Another study reported that these vacuoles are responsible for collecting the injurious elements and preventing them from interfering with the biological activities of these cells [25].
A study suggested that toxic effect of MSG on the liver reflects on histopathological changes such as distortion of hepatocytes and dilatation of central vein of the liver. He reported that MSG administration increased the enzyme activity (ALT and AST) as result of heptocellular injury and cause increased ratio of AST-to-ALT by $56.59 \%$ indicating possible cirrhosis [26].

These results are consistent with a study that showed that rat liver metabolized glutamate by oxidative deamination and then if large amounts of glutamate were ingested, hepatic metabolism of glutamate and toxic metabolites would be increased [18]

Hepatic fibrosis via collagen fibers deposition was demonstrated in the present study; this was in agreement with previous studies which reported that the treatment of rats with MSG induced an area of hepatic necrosis and fibrosis [17,21]. Moreover, [22] reported biliary proliferation and peribiliary fibrosis following treatment of rats with MSG.

Furthermore, a study suggested that oxidative stress might play a role in the development of hepatic fibrosis and degeneration [27].

The MSG caused depletion of glycogen content in the cytoplasm of hepatocytes in the treated rats with decrease in mucopolysaccharide granules after staining with P.A.S [28].

The MSG caused hyperinsulinemia that induced different alteration in the metabolic rate of glucose utilization; it decreases the antioxidant defenses. Therefore alteration in the metabolic rate was associated with oxidative stress in the hapatic tissue [29].

Administration of MSG induced chronic inflammatory disease because of presence of inflammatory cells in the liver tissue and depletion of carbohydrates in the cytoplasm of hepatocytes [17].

The cellular infiltration is a sign of chronic inflammation. Activation of macrophages occurs in the presence of particulate material and strong microbial antigens [25]. 
Electron microscopic study of Group (II) (Group treated with MSG); showed that the nucleus was severly shrunken. The hepatocytes showed vacuolated cytoplasm, shrunken mitochondria which were few in number. A study referred also that vacuolation may be due to disturbance of ionization of the cell with consequent retention of water and sodium leading to cellular swelling [30].

The results of the present study are in agreement with a previous study which showed that there were many ultrastructural abnormalities in the liver including vacuolation of the cytoplasm, vesiculated rough endoplasmic reticulum and atrophied mitochondria with ill-defined cisternae [14]

Cellular degeneration has been reported to cause cell death which is of two types namely apoptosis and necrotic cell death [31]

LM study of (Group III) (Vitamin C supplemented group); showed improvement in the structure of hepatic tissue as vitamin C led to marked reduction in the histopathological degeneration in tissues by toxic agents $[33,12]$. This protective effect of vitamin $\mathrm{C}$ against toxicity of MSG occured because of its antioxidant action and it is considered a free radical scavenger as vitamin $\mathrm{C}$ reversed some pathological changes which were induced in thymus of rats as result of administration of MSG [12].

A previous study suggested that the ameliorating effects of vitamin $\mathrm{C}$ was to be likely mediated via inhibition of free radicals generation and/or free radical scavenging activity [34].

Dietary antioxidants such as vitamin C, vitamin $\mathrm{E}$ and queritn have a protective effect against oxidative stress induced by MSG [35]

The results of Electron microscopic study of Group (III) (Vitamin C supplemented group); are in agreement with a previous study which showed that the ultrastructural changes of the hepatocytes of rats treated with MSG improved when treated with Vitamin C in the form of diminution of cytoplasmic dissolution, well-defined nucleolus and nuclear envelope. Moreover there was normal shape rough endoplasmic reticulum [14].

\section{Conclusion:}

- Chronic use of Monosodium glutamate (MSG) causes toxic effects on the liver tissue in the form of atrophy of hepatocytes and vacuolation of the cytoplasm and dilatation of central veins and sinusoids.
- Vitamin $\mathrm{C}$ can diminish these toxic changes induced by MSG on the liver tissue.

\section{References}

1- MOORE K.L.: Congenital malformations due to environmental factors: Developing Humans. W.B. Saunders co. Ltd Philadelphia, ${ }^{\text {nd }}$ ed. pp. 173-183, 2003.

2- ALAO O.A., ASHAOLU J.O., GHAZAL O.K. and UKWENYA V.O.: Histological and biochemical effects of monosodium glutamate on the frontal lobe of adult Wistar rats, International Journal of Biomedical and Health Sciences, 6 (4): 197-203, 2010.

3- NHIC (Natural Health Information Center): http://www. . Natural-Health-Information-Center.com ., 2008.

4- SAMUELS A.: The Toxicity/Safety of MSG: A Study in Suppression of Information. Accountability in Research, 6 (4): 259-310, 1999.

5- SCHWERIN P., BESSMAN S.P. and WAELSCH H.: The uptake of glutamic acid and glutamine by brain and other tissues of the rat and mouse, J. Biol. Chem., 184: 37-44, 1950.

6- BHATTACHARYA T., BHAKTA A. and GHOSH S.K. Long term effect of monosodium glutamate in liver of albino mice after neonatal exposure, Nepal Medical College Journal, 13 (1): 11-16, 2011.

7- ADRIENNE S.: The Toxicity Safety of MSG A study in suppression of information, Acct. Res., 6 (4): 259-310, 1999.

8- EWEKA A.O. and ADJENE J.O.: Histological studies of the effects of monosodium glutamate on the medial geniculate body of adult Wister rat, Electrone. J. Biomed., 2: 9-13, 2007.

9- SINGH K. and AHLUWALIA P.: Studies on the effect of Monosodium Glutamate (MSG) administration on some antioxidant enzymes in the arterial tissue of adult male mice, J.Nutr. Sci. Vitaminol (Tokyo), 49: 145, 2003.

10- PADAYATTY S.J., KATZ A., WANG Y., et al : "Vitamin $\mathrm{C}$ as an antioxidant: evaluation of its role in disease prevention.". Journal of the American College of Nutrition, 22 (1): 18-35, 2003.

11- MEVES A., STOCK S.N. and BEYERLE A.: Vitamin C derivatives a scorbyl palmitate promotes ultraviolet Binduced peroxidation and cytotoxicity in kertinocytes. J. Invest. Dermatol., 119 (5): 1103-1108, 2002.

12- BARROS P.S., SAFATLE A.M. and QUEIROZ I.: Blood and a aqueous humor antioxidants in cataractous poodles. Can. J. Opthalmol., 39 (1): 19-24, 2004.

13- MOHAMED K.I.: The Effects of Oral Dosage of Monosodium Glutamate Applied for Short- and Long-Terms on the Histology and Ultrastructure of Testes of the Adult Rats. Journal of Animal and Veterinary Advances, 11 (1): 124-133, 2012.

14- OSMAN H., ELSHAMA S. and EL-KENAWY A.: Study of the role of antioxidant (Vitamin C) on modulation toxicity of chronicuse of monosodium glutamate in liver of albino rats. Ain Shams J. Forensic Med. Clin. Toxicol., (19): 75-87, 2012.

15- DAS R.S. and GHOSH S.K.: Long term effects of monosodium glutamate on spermatogenesis following neonatal 
exposure in albino mice a histological study. Nepal. Med Coll J., 12 (3): 149-153, 2010.

16- SOLIMAN A.M.: Extract of coelatura aegyptiaca, a freshwater clam, ameliorates hepatic oxidative stress induced by monosodium glutamate in rats. African J. of Pharmacy and Pharmacology, 5 (3): 398-408, 2011.

17-ORTIZ G.G., BITZER-QUINTERO O.K., BEASZARATE C., RODRIGUEZ-REYNOSO S and LARIOS-ARCEO, F.: Monosodium glutamate-induced damage in liver and kidney: A morphological and biochemical approach. Biomedicine \& Pharmacotherapy, 60: 86-91, 2006.

18- BEYREUTHER K. BIESALSKI H.K. and FERNSTROM J.D.: "Consensus meeting: Monosodium glutamate - an update". Eur. J. Clin. Nutr., 61 (3): 304-13, 2007.

19- EWEKA A.O. and OM'INIABOHS F.: Histological studies of the effects of monosodium glutamate on the liver of adult Wister rats. The Internet Journal of Gastroenterol., 6: 2-10, 2008

20- EWEKA A.O., IGBIGBI P.S. and UCHEYA R.E.: Histochemical Studies of the Effects of Monosodium Glutamate on the Liver of Adult Wistar Rats. Ann. Med. Health Sci. Res., 1 (1): 21-29, 2011.

21- OSCAR O.W., EBENEZER O.F., GODWIN O.E., AGWU I.U. and GODFFERY O.O.: Effect of vitamin E on monosodium glutamate induced hepatotoxicity and oxidative stress in rats. Indian Journal of Biophysics, 43: 20-24, 2006.

22- EGBUONU A.C.C., OBIDOA O., EZEOKONKWO C.A., EZEANYIKA L.U.S. and EJIKEME P.M.: Hepatotoxic effects of low dose oral administration of monosodium glutamate in male albino rats. African Journal of Biotechnology, 8 (13): 3031-3035, 2009.

23- BHATTACHARYA T., BHAKTA A. and GHOSH S.K.: Long term effect of monosodium glutamate in liver of albino mice after neonatal exposure, Nepal Medical College. Journal, 13 (1): 11-16, 2011.

24- ABDEL HAMEED T.F.: Light and electron microscopic studies on the effect of orally administered formalin on liver and kidney of guinea pig, Journal of the Egyptian German Society of Zoology C. Histology and Histochemistry, 45 (c): 203-224, 2004.

25- CHEVILLE N.F.: Ultrastructural pathology: The comparative cellular basis of disease. 2 nd ed. Wiley-Blackwell. A John Wiley of Sons. Inc. USA., 2009.

26- SAKR S., OKADAH A. and EL-ABED F.: Gibberellin A3 induced histological and histochemical alterations in the liver of albino rats. Science Asia, 29: 327-331, 2003.

27- HAZAR Y., NAYIRA A., ABDEL B., ATTIA H.A.A. and FADDAH L.M.: Hepatoprotective effect of n-acetyl cysteine and/or $\beta$-carotene on monosodium glutamate induced toxicity in rats. Research Journal of Medicine and Medical Science, 2: 206-215, 2008.

28- MAHMOUD A.B., AL YAFEI A.H., KHIDR B.M. and EL-SHOKKARY G.H.: Role of melatonin and vitamin $\mathrm{C}$ in ameliorating monosodium glutamate induced oxidative stress and morphological changes in rats. Msc thesis department of zoology, faculty of science, Assiut University, 2010 .

29- DINIZ Y.S., FERNANDES L.A., CAMPOS K.E. and MANI F.: Toxicity of hypercaloric diet and monosodium glutamate: Oxidative stress and metabolic shifting in hepatic tissue. Food and Chemical Toxicology, 42 (2): 313-319, 2004.

30- HIGGINS C.M., JUNG C. and DING H.: Mutant Cu, Zn supreoxide dismutase that causes motonuron degeneration is present in mitochondria in the CNC. J. Neuro. Sci., 22: 215, 2003.

31- BRAUCHLE E., THUDE S. BRUCKER S.Y. and LAYLAND K.: Cell death stages in single apoptotic and necrotic cells monitored by Raman microspectroscopy Sci. Rep., 4: 4698. Published online 2014 Apr., 15. doi:10.1038/srep04698., 2014.

32- PAVLOVIC V., PAVLOVIC D., KOCIC G., SOKOLOVIC D., SARAC M. and JOVIC Z.: Ascorbic acid modulates monosodium glutamate induced cytotoxicity in rat thymus. Bratislavske Lekarske Listy, 110 (4): 205-209, 2009.

33- OKOLIE, N.P. and IROANYA C.U.: Some histological and biochemical evidence for mitigation of cyanide induced tissue lesions by antioxidant vitamins administration in rabbits. Food and Chemical Toxicology, 41 (4): 465 469, 2003.

34- BARJA G., LOPEZ TORRES M., PEREZ-CAMPO R., ROJAS C., CADENAS S., PRAT J. and PAMPLONA R.: Dietary vitamin $C$ decreases endogenous protein oxidative damage, malondialdehyde, and lipid peroxidation and maintains fatty acid unsaturation in the guinea pig liver. Free Radicals Biology and Medicine, 17: 105-115, 1994.

35- GULTEKIN F., DELIBAS N., YASAR S. and KILINC I.: In vivo changes in antioxidant systems and protective role of melatonin and a combination of vitamin $\mathrm{C}$ and vitamin $\mathrm{E}$ on oxidative damage in erythrocytes induced by chlorpyrifos-ethyl in rats. Arch. Toxicol., 75 (2): 8896, 2001. 


\section{تأثير جلوتامات أحادى الصوديوم على كبد ذكر الفأر البالغ والدور الوقائى المحتمل الموديوم (لفيتامين جين دكر)}

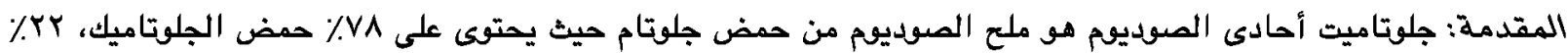

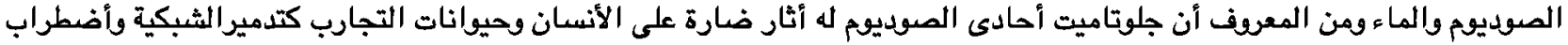

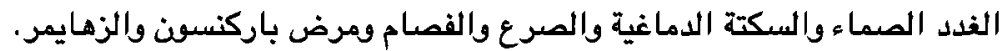

فيتامن ج (حمض الاسكوبيك) هو عنصر غذائي أساسي للبشر وبعض الأنقاع الصيوانية الأخرى في الكائنات الحية، يعمل أسكوربات

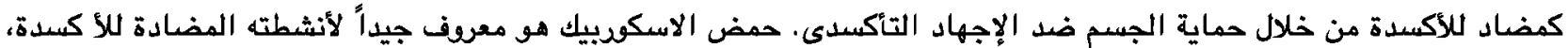

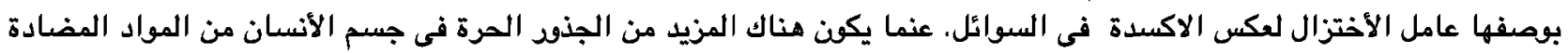

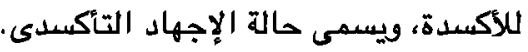

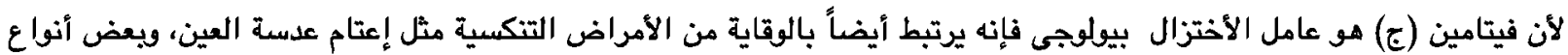
السرطان وأمراض القلب والأومية الدموية.

الغرضن من البحث: دراسة التأثير المحتمل من فيتامين ج على تلف الكبد الناجم عن جلوتامات أحادى الصوديوم فى الفئران الذكور البالغني.

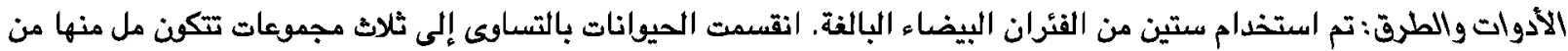

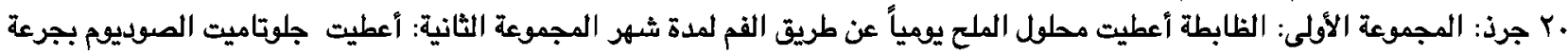

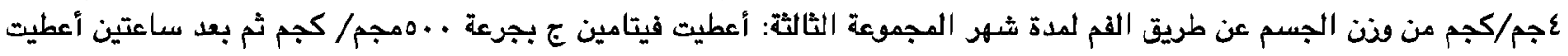

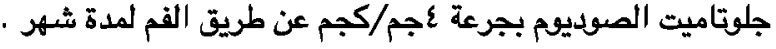

فى نهاية التجربة، تم تخدير الفئران بواسطة الأتير ثم الحقن بالفورمالين · 1 تم فتح البطن وتم استخراج الكبد من المجموعة الضابطة

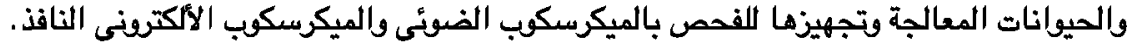

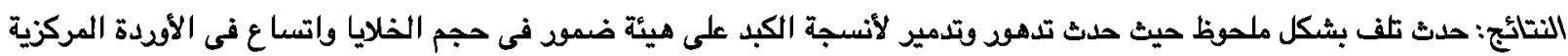

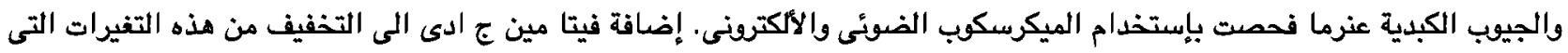

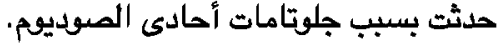

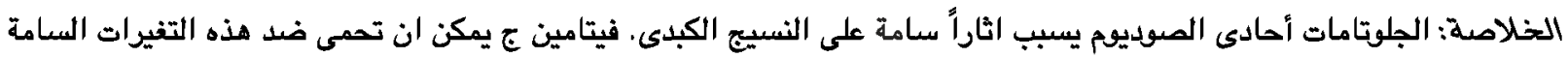
التى وقعت من قبل جلوتامات أحادى الصوديوم على أنسجة الكبد . 